\title{
Post-truth and Disinformation: Using discourse analysis to understand the creation of emotional and rival narratives in Brexit ${ }^{1}$
}

\section{Post-verdad y desinformación: uso del análisis del discurso para comprender la creación de narrativas emocionales y rivales en Brexit}

\author{
Pós-verdade e desinformação: Usando a análise do \\ discurso para entender a criação de narrativas emocionais \\ e rivais no Brexit
}

\author{
Laura Cervi \\ Universitat Autònoma de Barcelona (España) \\ laura.cervi@uab.cat \\ Andrea Carrillo Andrade ${ }^{3}$ \\ Pontificia Universidad Católica del Ecuador (Ecuador) \\ acarrillo745@puce.edu.ec
}

Fecha de recepción: 10 de abril de 2019

Fecha de recepción evaluador: 25 de abril de 2019

Fecha de recepción corrección: 10 de mayo de 2019

\footnotetext{
${ }^{1}$ This study has been conducted by self-founds by Andrea Carrillo Andrade and Laura Cervi.

${ }^{2}$ Laura Cervi. Investigadora Postdoctoral del Departamento de Periodismo y Ciencias de la Comunicación de la UAB. Doctora en Ciencia Política por la Universitá di Pavia y por la UAB. Parte del grupo de investigación Gabinete de Comunicación y Educación de la UAB. ORCID: https://orcid.org/0000-0002-0376-0609

${ }^{3}$ Andrea Carrillo Andrade. Máster en Ciencia Política por la Universidad Autónoma de Barcelona (UAB) y licenciada en Comunicación por la Pontificia Universidad Católica del Ecuador (PUCE). Miembro del Grupo de Investigación en Ciencias de la Comunicación de la PUCE. ORCID: https://orcid.org/0000-0002-0779-6991
} 


\begin{abstract}
The present research explores the concept of post-truth and disinformation in regard to Brexit. It is a qualitative and exploratory investigation. It uses Critical Discourse Analysis (CDA) to take a look into the speeches of politicians during the Brexit campaign. The research matches seven characteristics of post-truth with four of the five levels of disinformation according to conceptual parameters. At the end, it concludes that politicians use emotional and rival narratives to create a brief political polarization.
\end{abstract}

Keywords: post-truth, disinformation, emotional narratives, rival narratives, Brexit

\title{
Resumen
}

La presente investigación explora el concepto de post-verdad y desinformación con respecto al Brexit. Es una investigación cualitativa y exploratoria. Utiliza el Análisis Crítico del Discurso (CDA) para echar un vistazo a los discursos de los políticos durante la campaña Brexit. La investigación combina siete características de la post-verdad con cuatro de los cinco niveles de desinformación según los parámetros conceptuales. Al final, concluye que los políticos usan narrativas emocionales y rivales para crear una breve polarización política.

Palabras clave: post-verdad, desinformación, narrativas emocionales, narrativas rivales, Brexit

\section{Resumo}

A presente pesquisa explora o conceito de pós-verdade e desinformação em relação ao Brexit. É uma investigação qualitativa e exploratória. Ele usa a Análise Crítica do Discurso (CDA) para dar uma olhada nos discursos dos políticos durante a campanha do Brexit. A pesquisa combina sete características da pós-verdade com quatro dos cinco níveis de desinformação de acordo com parâmetros conceituais. No final, conclui que os políticos usam narrativas emocionais e rivais para criar uma breve polarização política.

Palavras-chave: pós-verdade, desinformação, narrativas emocionais, narrativas rivais, Brexit

\section{Introduction}

Boyd (2017) outlined that in the current system, people are leading a war, the information war. In 2016, "post-truth" was awarded as the word of the year by Oxford dictionaries. This word was used when referring to the United States' Presidential Elections and Brexit referendum. In both campaigns, journalists claimed that politicians profited from disinformation to manipulate public support (Drake, 2017; Masters 2018).

Brexit was the winner name (over Bremain) to refer to the referendum where the United Kingdom voted on holding a continued membership of the then European Communities. It took place on June 23th, 2016. The "leave" won with the $51.9 \%$ of votes. According to Hobolt (2016), the divide between winners and losers of globalization was a key driver of the vote: 
Preferring to "leave" was particularly common among less-educated, poorer and older voters, and those who expressed concerns about immigration and multi-culturalism.

On one hand, the concept of post-truth is still under construction. Scholars (Ball, 2017; D' Ancona, 2017), when referring to post-truth, affirm that it is the consequence of a crash in the value of truth and that it comes once honesty and accuracy are no longer a priority in a political exchange.

On the other hand, researchers (Fetzer, 2004; National Endowment for Democracy, 2017) agree to understand disinformation as a "deliberate effort to mislead, deceive, or confuse an audience in order to promote their personal, religious, or ideological objectives", but it is not necessarily composed of outright lies or fabrications.

Thus, it is easy to intuit that post-truth and disinformation describe a complex environment where three main actors are involved: citizens, media and politicians. The present research will focus on politicians. To do so, it will look for the main characteristics of posttruth and how they are related to different levels of disinformation. Then, it will identify the combination of the - previously recognized- main characteristics of post-truth in political speeches during the Brexit campaign. It will consider how the context shapes the use of different mechanisms among politician's discourses in order to try how disinformation is planned and how it involves a technically sophisticated deceit.

\section{Theoretical Framework}

As it has been outlined, post-truth is an under-construction concept. Oxford Dictionaries developed the most-used and quoted definition of post-truth. According to this institution, posttruth is an adjective that relates or denotes "circumstances in which objective facts are less influential in shaping public opinion than appeals to emotion and personal belief" (Oxford Dictionaries, 2018). Then, it is important to review the most important conceptualizations: 
Table 1: Confrontation of post-truth concepts and characteristics

\begin{tabular}{|c|c|c|c|}
\hline Author & Post-truth characteristics & Support in other literature & Confrontation \\
\hline $\begin{array}{l}\text { Higgins } \\
\text { (2016: 9) }\end{array}$ & $\begin{array}{l}\text { What differs post-truth } \\
\text { politics from the cliché that } \\
\text { all politicians lie and make } \\
\text { promises that they have no } \\
\text { intention of keeping is that in } \\
\text { the second scene; honesty is } \\
\text { still a default position, while } \\
\text { in post-truth politics this } \\
\text { expectation is no longer held. } \\
\text { In words of Higgins, } \\
\text { "political leaders take their } \\
\text { right to lie as a given, perhaps } \\
\text { particularly when the lies are } \\
\text { transparent". }\end{array}$ & $\begin{array}{l}\text { Certainly, in politics the lie or } \\
\text { the half-truth have always been } \\
\text { resources handled with ease, } \\
\text { but, now, the response to the } \\
\text { political and economic status } \\
\text { quo has introduced } \\
\text { sentimental, emotional } \\
\text { elements, in their false } \\
\text { messages giving them strength } \\
\text { devastating (Zarzalejos, 2017: } \\
\text { 12) }\end{array}$ & $\begin{array}{l}\text { Lynch (2017) relates post-truth } \\
\text { with Bloor's postulates of } \\
\text { symmetry and impartiality. } \\
\text { The latter states that it is not } \\
\text { necessary to determine that a } \\
\text { candidate belief is false, } \\
\text { irrational, or self-defeating in } \\
\text { order to set up the salience of a } \\
\text { social explanation. While, } \\
\text { symmetry should be regarded } \\
\text { as a "style of explanation in } \\
\text { which the same types of cause } \\
\text { would explain, say, true and } \\
\text { false beliefs" (Bloor in Lynch, } \\
\text { 2017: 595). }\end{array}$ \\
\hline $\begin{array}{l}\text { The } \\
\text { Economist } \\
\text { (2016) }\end{array}$ & $\begin{array}{l}\text { In politics, "post-truth" is a } \\
\text { reliance on assertions that } \\
\text { "feel true" but have no basis } \\
\text { in fact. The term picks out the } \\
\text { heart of what is new: that } \\
\text { truth is not falsified, or } \\
\text { contested, but of secondary } \\
\text { importance }\end{array}$ & $\begin{array}{l}\text { "In politics, as in everyday life, } \\
\text { two sets of often competing } \\
\text { constraints shape our } \\
\text { judgements: cognitive } \\
\text { constraints, imposed by the } \\
\text { information we have available, } \\
\text { and emotional constraints, } \\
\text { imposed by the feelings } \\
\text { associated with one conclusion }\end{array}$ & $\begin{array}{l}\text { This definition is } \\
\text { asymmetrical, not neutral, and } \\
\text { in fact, there is a dichotomy } \\
\text { between objective facts on one } \\
\text { side and emotion and belief on } \\
\text { the other (Fuller, 2016) }\end{array}$ \\
\hline $\begin{array}{l}\text { Hoes } \\
(2017)\end{array}$ & $\begin{array}{l}\text { The aim of post-factualism is } \\
\text { to introduce doubt rather than } \\
\text { to make people believe in a } \\
\text { shared } \\
\text { consensus. }\end{array}$ & $\begin{array}{l}\text { or another" (Westen, 2007: } \\
\text { 1849). }\end{array}$ & \\
\hline
\end{tabular}

\footnotetext{
${ }^{4}$ When referring to facts, it is important to take a look into what Poovey (1998) discovered; since the beginning of the 19th century, facts have two functions: description and interpretation. This means that numbers contain a hypothesis on what should be counted; moreover, these quantifications shape the systematic knowledge of the world (Poovey in Sprandel, $\mathrm{n} / \mathrm{d}$ ).

On the other hand, a feeling thermometer is a common survey tool used by researchers to determine and compare respondents' feelings (in a numerical or categorical scale) about a given person, group, or issue. Hence, with this tool, feelings are seen as measurable. Besides, in 2005, the term "truthiness" (Newman et al., 2012) describes that people "feel true" a certain statement.

${ }^{5}$ Many scholars (Jasanoff, 2004; Asch, 1935) have already explored the idea that facts are socially constructed. The motivated reasoning paradigm and confirmation bias (Ditto and López, 1992) are also related to this phenomenon: how people process information depends not only on the data itself, but in their experience and goals.
} 


\begin{tabular}{|c|c|c|c|}
\hline $\begin{array}{l}\text { Roberts } \\
(2010) \\
\text { D'Ancona } \\
(2017)\end{array}$ & $\begin{array}{l}\text { Post-truth refers to a political } \\
\text { culture in which politics are } \\
\text { almost disconnected from } \\
\text { policy (the substance of } \\
\text { legislation) } \\
\text { Post-truth shows that an } \\
\text { indifference to truth has } \\
\text { become the "norm" in } \\
\text { politics, people prefer to vote } \\
\text { not for what they trust in, but } \\
\text { based on what they seem } \\
\text { capable of. }\end{array}$ & $\begin{array}{l}\text { Political polarization is a } \\
\text { condition that stimulates post- } \\
\text { truth and vice versa. Vegetti } \\
\text { (2014: 230) relates political } \\
\text { polarization with higher levels } \\
\text { of impact in partisanship on } \\
\text { perceptions of party ideology } \\
\text { and competence (illusion of } \\
\text { competence). }\end{array}$ & $\begin{array}{l}\text { Roberts (2010) conducted a } \\
\text { survey to conclude that voters } \\
\text { chose a party based on value } \\
\text { affiliations; they adopt } \\
\text { opinions of the tribe, develop } \\
\text { arguments to support these } \\
\text { opinions and subsequently, } \\
\text { they select facts to reinforce } \\
\text { their statements. }\end{array}$ \\
\hline $\begin{array}{l}\text { D' Ancona } \\
\text { (2017: 15). }\end{array}$ & $\begin{array}{l}\text { The creation of a conflict is } \\
\text { also a characteristic of post- } \\
\text { truth as what matters is not } \\
\text { veracity, but impact. }\end{array}$ & & \\
\hline
\end{tabular}


All these characteristics and conceptualizations lead to think that those aspects of post-truth that can become clearly identified in discourse analysis. Additionally, the last two aspects of post-truth are directly related to political polarization. In the lines below, the most used characteristics of post-truth will be related to codes for discourse analysis and will be linked to one or more of the levels of disinformation -related to Fetzer's (2004) categorization.

\section{Disinformation}

While the concept of post-truth has been built towards the idea of "facts", disinformation is related to "information". There is a subtle difference between facts and information: A fact is a statement, but information is a set of facts or details that are delivered.

According to Fetzer (2004), disinformation can entail the distribution, assertion, or dissemination of false, mistaken, or misleading information. This action is always intentional and looks forward to misleading, deceive, or confuse. Fetzer (2004) classified disinformation in five levels:

Table 2: Levels of disinformation

\begin{tabular}{|l|l|}
\hline Level & Description \\
\hline First & Disinformation might equally well be characterized as mere incompetence. \\
\hline Second & It occurs when available evidence that is relevant is dismissed or ignored. \\
\hline Third & $\begin{array}{l}\text { It happens by attacking the author of the statement instead of the position } \\
\text { that they represent. }\end{array}$ \\
\hline Fourth & It is related to the creation of a highly biased impression. \\
\hline Fifth & $\begin{array}{l}\text { It occurs when a source presents information that has been deliberately } \\
\text { selected to misrepresent, distort, or abuse the target with the intention to } \\
\text { mislead. }\end{array}$ \\
\hline
\end{tabular}

\section{Research Questions}

The aim of this research is to observe how do the main characteristics of posttruth combine to disinform in political speeches during polarized elections. In this sense, the broader question would be: What are the main characteristics of post-truth?

Once the main characteristics of post-truth are identified, the second step is to select those characteristics that are observable in political speeches:

$R Q 1:$ How are the characteristics of post-truth combined in speeches?

However, as post-truth is a combination of social and political factors, it is imperative to take into account the environment in which it is developing. Moreover, how this context shapes the politic speeches. Thus, the second and third questions are: 
RQ2: How does the context shape the use of the different mechanisms to disinform?

RQ3: How do disinformation and post-truth work in Brexit?

\section{Research design and Methodology}

\section{Research Strategy}

As the concept of post-truth is still under construction, an exploratory and qualitative approach is required -that is why the first part has been determined as an author confrontation-.Then, as scholars (Rose, 2016; Ball, 2016; D' Ancona, 2017) agree in looking to the United States Presidential Election and Brexit as the iconic (crucial) cases of the phenomenon, the study of them is a good starting point. Because of the nature of the referendum, Brexit is useful to examine whether and how politics are almost disconnected from policy. Moreover, it is a more interesting exercise to identify disinformation in a democratic regime as authors (Golitsyn, 2016) argue that in this kind of regimes, disinformation is more veiled. In this sense, a participatory observation has been lead as a data collection method (Kawulich, 2005).

Secondly, this research is also planning to be qualitative. Qualitative research allows to look for elements in a "multi-layered and textured social world" (Mason, 2002: 3 ). This type of research is capable of producing very well-founded cross-contextual generalities.

Thirdly, this investigation uses discourse analysis because of the main goal that it pursues, which consists of linking the characteristics of post-truth and disinformation. This method allows considering the structure of language itself as "one element of the relatively durable structuring and networking of social practices" (Fairclough, 2003: 3). Besides, as Teun Van Dijk (2005) underlines from the analysis of ideological discourse, the characterization of how a group language is built determined mostly favors participants of that group and the presentation positive to be made of it". Hence, discourse analysis will be helpful to understand the mechanisms and the ideologies that are broadcasted by politicians.

With all these considerations, it is imperative to justify units of analysis according to the objectives of this research.

\section{Units of Analysis}

Two periods of time in Brexit should be considered: April-May 2016, when the EU referendum campaign officially started (first major speeches) and June 21st, the last day politicians where able to speak before voting (closing speeches). The reason for this selection is, obviously, time: to look for the evolution of the statements from the beginning to the end. 
As the whole process Brexit was catalogued as post-truth, the speeches of the politicians from both sides (Remain and Leve) should be studied. According to scholars and media (Clarke et al., 2017; Shipman, 2016; Colvile, 2016) those are David Cameron (Prime Minister of the United Kingdom and leader of the Remain campaign), and Boris Johnson (one of the most senior figures in executing the UK's decision to leave the European Union). Both politicians belong to the British Conservative Party. This aspect is one of the strengths of this investigation because it stresses on the generation of conflict -even inside the same political party- which is one of the main characteristics of posttruth; moreover, it is more useful to take an insight on how politicians that are supposed to share a common ideology, regard and frame a policy in an opposite way. Besides, the British Conservative Party historically has played a significant role in the Brexit process.

Table 3: Units of analysis

\begin{tabular}{|l|l|l|l|}
\hline $\begin{array}{l}\text { Position } \\
\text { towards Brexit }\end{array}$ & Actor & Political party & Speeches \\
\hline Remain & David Cameron & $\begin{array}{l}\text { British } \\
\text { Conservative } \\
\text { Party }\end{array}$ & $\begin{array}{l}\text { 28 of April: PM speech at } \\
\text { Caterpillar factory } \\
\text { in Peterborough on the EU } \\
\text { referendum }\end{array}$ \\
\hline $\begin{array}{l}\text { 21 of June: Last-ditch plea for } \\
\text { Britain to Remain }\end{array}$ \\
\hline Leave & Boris Johnson & $\begin{array}{l}\text { British } \\
\text { Conservative } \\
\text { Party }\end{array}$ & $\begin{array}{l}\text { 9 of May: Boris Johnson MP made } \\
\text { his first major speech (post-deal) } \\
\text { on the EU at the Vote Leave }\end{array}$ \\
\hline $\begin{array}{l}\text { 21 of June: EU debate BBC's } \\
\text { Great Debate }\end{array}$ \\
\hline
\end{tabular}

According to the five characteristics (categories) of post-truth in relationship with polarized elections, and the classification of disinformation, seven codes were created:

\footnotetext{
${ }^{6} \mathrm{https}$ //www.gov.uk/government/speeches/pm-speech-at-caterpillar-on-the-eu-referendum-28-april-2016

${ }^{7}$ https://www.independent.co.uk/news/uk/politics/eu-referendum-brexit-latest-live-david-cameron-fullspeech-remain-leave-a7093426.html

${ }^{8} \mathrm{http}: / /$ www.voteleavetakecontrol.org/boris_johnson_the_liberal_cosmopolitan_case_to_vote_leave.html

${ }^{9} \mathrm{https}: / /$ www.youtube.com/watch? $\mathrm{v}=\mathrm{nH} 2 \mathrm{NpCaSjBE}$
} 
Table 4: Categories and codes' explanation

\begin{tabular}{|c|c|c|c|}
\hline $\begin{array}{l}\text { Post-truth characteristics } \\
\text { (categories) }\end{array}$ & Code & $\begin{array}{l}\text { Level of } \\
\text { disinfor } \\
\text { mation }\end{array}$ & Codes' explanation \\
\hline \multirow{2}{*}{$\begin{array}{l}\text { Political leaders take their } \\
\text { right to lie as a given, perhaps } \\
\text { particularly when the lies are } \\
\text { transparent. }\end{array}$} & Use of facts ${ }^{2}$ & $4^{\text {th }}, 5^{\text {th }}$ & Use of facts to sustain an argument. \\
\hline & Transparency & $4^{\text {th }}$ & $\begin{array}{l}\text { Lack or absence of arguments by the use of } \\
\text { intertextuality, assertion and assumption. }\end{array}$ \\
\hline \multirow{2}{*}{$\begin{array}{l}\text { Post-truth is a reliance on } \\
\text { assertions that "feel true" but } \\
\text { have no basis in fact. }\end{array}$} & Capability & $3^{\text {rd }}$ & $\begin{array}{l}\text { Statements that legitimate the speaker position and } \\
\text { delegitimize the others. }\end{array}$ \\
\hline & Feelings/emotions & $2^{\text {nd }}$ & $\begin{array}{l}\text { Statements that appeal for an emotional reaction on } \\
\text { public (fear, anger or enthusiasm }{ }^{3} \text { ), assumptions, and } \\
\text { values. }\end{array}$ \\
\hline $\begin{array}{l}\text { Politics are almost } \\
\text { disconnected from policy (the } \\
\text { substance of legislation). }\end{array}$ & Juxtaposition of meanings & $5^{\text {th }}$ & $\begin{array}{l}\text { Calculative selection of statements for the values } \\
\text { they evoke: } \\
\text { - How do they address the policy as itself } \\
\text { - How particulars come to be represented as } \\
\text { universals } \\
\text { - (Risky) framing and contextual sensitivity }\end{array}$ \\
\hline $\begin{array}{l}\text { People prefer to vote not for } \\
\text { what they trust in, but what } \\
\text { seems capable. }\end{array}$ & Predictions and promises & $\begin{array}{l}2^{\text {nd }}, 4^{\text {th }}, \\
5^{\text {th }}\end{array}$ & $\begin{array}{l}\text { Evidential and causal beliefs; visions of the future } \\
\text { that are based on modelling and assumptions about } \\
\text { future trends. }\end{array}$ \\
\hline $\begin{array}{l}\text { The creation of a conflict is } \\
\text { also a characteristic of post- } \\
\text { truth as what matters is not } \\
\text { veracity, but impact. }\end{array}$ & Conflict & $3^{\text {rd }}$ & $\begin{array}{l}\text { Statements that underline the differences between the } \\
\text { other's proposals in a more personal level. }\end{array}$ \\
\hline
\end{tabular}

\section{Results}

The results will follow the structure of Fairclough's (2001). It will present a threelevel framework involving textual analysis, interpretation of this in view of the members' resources and situational context, and explanation of the reproduction of discursive practices within a matrix of relations. The content analysis was done using Atlas.ti. Atlas.ti is a computational tool applied for the objective, systematic and qualitative description of the manifest or implicit content of a source data (Varguillas, 2006).

${ }^{10}$ Every level of disinformation was linked to a characteristic of post-truth according to conceptual parameters.

${ }^{11}$ This code has an extra step. After recognizing all the facts that were used, they were classified into "true", "mostly true", "half true", "mostly false" and "false". This process is fact checking. To classify the facts, the parameters and scales of Polifact (2018) were used. This site won a Pullitzer prize because of its factchecking.

12 These emotions are discrete, which affect how individuals deal with threats and how they seek out, process and use information (Vasilopoulou and Wagner, 2017). 


\section{Text Analysis}

The seven codes - defined in Table 3- are related with the characteristics of posttruth that had been identified by scholars and journalists. The relationship between these codes and the levels of disinformation is determined by definition. These codes have to be seen also as resources that politicians use according to the context. For instance, how politicians frame an issue (juxtaposition of meanings [fourth and fifth level of disinformation]) will depend on the context. These codes will permanently overlap but this is a feature of rhetoric.

\section{Conflict}

In this study, conflict was defined as the "statements that underline the differences between the other's proposals in a more personal level". It is related with the third level of disinformation.

As post-truth seeks for impact, it is important to explicit the obviousness of the role of the actors and of their proposals. Cameron's speeches reflect a very low use of this characteristic. But, generating conflict is one of the strongest mechanisms for Johnson and it is permanent in the campaign. The words of Boris Johnson in his closing speech reflect this:

At the end of this campaign I think you pretty know that there is a very clear choice between those in that side who speak of nothing but fear of the consequences of leaving the EU and we in our side who offer help. Between those who have been endlessly rubbishing our country and running it down and those of us who believe in Britain [emphasis mine].

Johnson's selection of words emulates a permanent contraposition and a dichotomy: Leaving as a bet for England and its capabilities that will be magnified with the help of everybody (the people), versus remaining as accepting the "unfair" rules of the European Union because of fear.

Additionally, this statement reflects a contraposition between powers; there is a dichotomy between 'ordinary' and 'elite'. Remain represented the status quo and expert opinion in telling people, largely truthfully, that leaving would be a risk. Leaving encouraged people to vote for a change. With these arguments, Johnson is calling for a punishment to Cameron (and then to Remain) at the ballot box. Then, the information that is presented is clearly not related to the policy as itself, but about the author of it (third level of disinformation).

\section{Capability}

In this study, capability is defined as the statements that legitimate the speaker position and delegitimize the others. This resource was more used at the beginning of the campaign rather than at the end; and Cameron used it the most. However, this characteristic is also dichotomous. While Johnson specializes to attack, Cameron is 
worried about attacking and defending. For instance, this is how Johnson referred to Cameron at the beginning of the campaign:

It is above all bizarre for the Remain campaign to say that after the UK agreement of February we are now living in a "reformed" EU, when there has been not a single change to EU competences, (...) nothing remotely resembling the agenda for change that was promised in the 2013 Bloomberg speech [Emphasis mine].

Then Cameron repeatedly faced the attack through the "reformed" EU issue, but he also needed to attack the promises that the Leave campaign was making to underline how non-viable they were. Also, he tries to underline that the politicians that are willing to leave are not competent:

One minute they say we're going to be like Norway and have full access to the market (...) Then they say let's have a trade relationship like Canada. Well that's a good deal for Canada, but they're thousands of miles away from the European continent.

On one hand, Johnson does not worry to defend himself for what Cameron states to cast doubt towards the Leave campaign. A plausible explanation is that post-truth is, first and foremost, an emotional phenomenon. It concerns to citizens' attitude to truth, rather than truth itself. Therefore, voters are predisposed to trust in some statements. This is strongly related to the second level of disinformation as it may often "appear to violate this principle and qualify as irrationality of belief" (Fetzer, 2004).

Then, Boris Johnson lacked arguments towards Cameron's claims, however, Johnson also realized that he did not need them, because Cameron's statements were not provocative enough. Thus, voters will not demand for an answer.

On the other hand, at the beginning Cameron bet to deploy facts to fight the permanent attacks that he received from Leave campaign. His arguments were supported by historical and geopolitical facts as it can be evidenced in the last quotation; however, for the closing speech Cameron changed his style and he preferred to be more ambiguous.

Additionally, as the negotiations with EU had been the most important job during his government, during the whole campaign he remarked the differences towards UK and the rest of the EU members.

\section{Predictions/Promises}

David Cameron used many predictions while Johnson, promises. In his opening speech, Cameron said:

[I]n the European Union, with 27 countries behind us, we can take a stronger lead in tackling climate change, fighting disease and poverty, standing up to Russian aggression, helping friends around the world - in South East Asia, Australasia, the Caribbean and we can promote and preserve the values we hold so dear-like democracy, like freedom, like tolerance. 
Cameron's argument reflects an evidence-based prediction of what the United Kingdom could receive if they remain in the EU. However, the benefits that he is permanently exposing are related to security. This because Cameron is not able to make promises in terms of economic decisions, just in terms of trade. The Eurozone crisis highlighted that the UK had to allow changes deemed by the Eurozone members to save the Eurozone, in discussions in which, inevitably the UK was not present as it is outside the monetary union.

Cameron's statement is also a call for people to trust in what he has already been doing and to think not just in terms of Europe, but in the UK as part of the globe. Besides, it tries to reflect a vision of superiority of the United Kingdom over the other members of the UE: "with 27 countries behind us". So far, this code is a combination of the fourth and fifth level of disinformation as the selection of the facts is clearly biased; however, nobody can judge for sure the quality -accuracy- of the information.

On the other side, the Remain campaign's main attack line was a promise: "We send the EU 350 million a week - let's fund our NHS ${ }^{13}$ instead".

It is obvious that Boris Johnson and the Leave campaign can develop a more provocative speech towards a future that he is not responsible for bringing ${ }^{14}$. That is why Oakeshott (in Ball, 2017: 63-4) published: "Leave wasn't a political party with a manifesto. This fell well short of the definition of a pledge. "Let's meant "we could"; not "we will". However, Cameron, as he is part of the government, has to be more careful about the promises because he will be responsible for making them accountable.

Then, unattainable promises are matched by unreasonable expectations; unachieved objectives are part-concealed by euphemism and evasion: the gap between rhetoric and reality breeds disenchantment and distrust.

In both cases, politicians use a set of conditions rather than a real situation to explain to voters their claims. Thus, the arguments that both politicians use are biased (fourth level of disinformation): In the case of Cameron, he states a series of conditions (assumptions) in which people may feel threatened to prevent them from voting to leave. In Johnson, his promises are based in facts which sources have never been clear. Then, this code is also related to the second level of disinformation as some evidence is always dismissed according to the convenience of the politicians.

\footnotetext{
${ }^{13}$ NHS stands for the National Health System. It is funded out of general taxation.

${ }^{14}$ Boris Johnson is an outrider. This means that he is able to make promises that he has no power to deliver. Also, both politicians (Cameron and Johnson) had a different audiences: While Cameron focuses on predictions, Johnson seeks for promises.
} 


\section{Juxtaposition of Meanings}

Euroscepticism is the perfect issue to juxtapose meanings: Since the beginning, Cameron decided to frame the issue using the premise that the UK is different from other EU's members and that the EU is aware of the power that the country has. On the other hand, he underlined the economic benefits that the membership represented because of the four freedoms (goods, capital, services, and labor): "we are better off as an economy, better off for jobs, better off for investment if we stay inside a reformed European Union". This can be the strongest premise of his speech and it was used also in the closing speech: "Out of the Euro. Keeping our borders. Not involved in ever-closer union. We have the best of both worlds".

Secondly, Cameron has been using repeatedly the adjective "reformed" when referring to the European Union. This despite the fact that the negotiations in which he worked on since the Bloomberg speech (2013) did not have the expected results. However, he needs to set the idea that there has been a change and that he will be able to keep working on changes while remaining as a part of the EU.

Cameron's third argument is that while remaining, the UK will be safer: "First is, I believe Britain will be stronger if we stay inside the European Union". "I think will be safer". This last argument used to generate and stress fear among voters as terrorism is completely uncertain. Along the whole campaign, these arguments remained and they were exposed repetitively.

Johnson decided to frame the referendum in regard to what he named as "myths". He went for arguments that counterpoised political independence and economic benefits, the peace-in-Europe argument and the Anti-European sentiment.

For the first myth he said that the EU is always stating laws and regulations (mostly related with trade and business). Then, the UK has to accept them but it has no power of decision. The contraposition economy vs. political independence is important because the nostalgia of power is strong for such a powerful nation like UK. This rhetoric evokes a glorious past that has been lost because of the passivity of bureaucratic politicians (EU), which it also includes a promise of restoration.

For the second myth, Johnson pleads that the EU relates peace with trade. However, according to him, the Eurozone is a disaster: "And what are they saying now, when the ensuing single currency has become a disaster? "More Europe!" Additionally, Johnson stablishes that the EU weakens democracy because the power of the Parliament. He uses Greece as an example: "It is a complete humiliation, a sense of powerlessness (...) That is what happens when you destroy democracy".

For the third myth, Johnson is categorical: "there is simply no common political culture in Europe". 
By the end of the campaign, Johnson determined that the most moving argument was the economic one, because the claim of giving money to NHS was provocative for voters. That is why he prefers to emphasize this argument.

Euroscepticism and Brexit are good examples of what is known as "special pleading" (related to disinformation type five) as the policy has so many points to consider but it is hard to explain them to average voters.

\section{Feelings/Emotions}

In the West, emotional connection is always part of the political decision-making. However, when it comes to post-truth, the objective is to trigger emotions, not to win an evidence-based debate. When coding "feelings/emotions", most of the statements overlapped with "juxtaposition of meanings" and "conflict".

When it comes to feelings, politicians rely on previous values that they intuit voters have already developed above other issues. Then, it is very hard to find a statement that evokes a feeling directly. There is more a mixture of other mechanisms to provoke feelings.

In the case of Cameron, he seeks for fear:

If we go, that's the end of reform in Europe. I think it would slip backwards and we would be left outside. And (...) we might have the impression of greater sovereignty but we wouldn't have the ability to get things done.

Fear is related to the avoidance/surveillance system. Scholars (Brader et al., 2008; Carver and Harmon-Jones, 2009; Druckman and McDermott, 2008) affirm that fear leads to an increased search for information. Besides, fear makes individuals more risk-averse and cautious. Therefore, it makes sense that Cameron seeks for stimulating fear because (1) he will be governing once the decision has been made so he knows the risks and (2) he has access to all the information that evidence how non-viable is the leaving option. Thus, he is able to answer to voters once they look for information. This has not changed during all the campaign.

In the case of Boris Johnson, he prefers to provoke anger and he accomplishes it by using and emotional narrative full of rhetorical questions:

Do we feel loyalty to that [EU] flag? Do our hearts pitter-patter as we watch it flutter over public buildings? On the contrary. The British share with other EU populations a growing sense of alienation, which is one of the reasons turn-out at European elections continues to decline.

This politician is capable of creating a story with an atmosphere that lead people to feel the EU like an institution which is completely apart from them. Anger lowers risk estimates, then, it is useful because the consequences of leaving the EU are uncertain. Johnson uses anger (also related with the creation of conflict) during the whole campaign. 
Enthusiasm is different from anger and fear because it has a positive valence. It is associated with a positive goal-oriented behavior. This feeling has the property of reinforcing people's habitual behaviors and existing political choices (e.g. partisanship). Enthusiasm is used by both actors, but in different ways: Johnson framed the referendum as an opportunity for change while Cameron calls for feeling that the UK is already extraordinary and that it does not need a change; he shows a speech towards being brave and patient.

This mechanism is related to the second level of disinformation because the appealing to feelings -especially when it comes to anger and enthusiasm-facilitate that relevant information can be dismissed or ignored. Once again and as it was exposed in the theoretical framework, the ways of knowing the world are inseparably linked to the ways in which people seek to organize and control it.

\section{Use of facts}

This category is one of the most important for this study as it is directly related to the definition of post-truth given by Oxford Dictionaries and with the concept of disinformation. It is imperative to understand that, in fact, the idea of objectivity through the use of facts should disappear, as it has been stated previously, facts have always been interpreted. However, what characterizes post-truth is that politicians select or ignore certain facts (fifth level of disinformation), they mix facts and opinion and they frame them to give a sense of the voter's world (fourth level of disinformation). In the words of Keyes (2004), politicians are able to "stretch" the truth.

The code "use of facts" was used when the politician pointed to a fact. After processing the speeches, the facts that were mentioned were classified into the categories true, mostly true, half true, mostly false and false ${ }^{15}$. This process is known as factchecking.

As Graph N. ${ }^{\circ} 1$ and N. ${ }^{\circ} 2$ show, most of the facts that were used by politicians from the Remain and the Leave campaign have been catalogued as "true" which means that the statements are accurate and there's nothing significant missing (Polifact, 2018). However, a deeply insight underlines, for instance, that when it comes to economy, the facts tend to present more relativeness in terms of accuracy.

\footnotetext{
${ }^{15}$ The methodology is the same used by PolitiFact (2018). This because the principles of the Truth-o-meter set by this independent project won a Pulitzer Prize.
} 


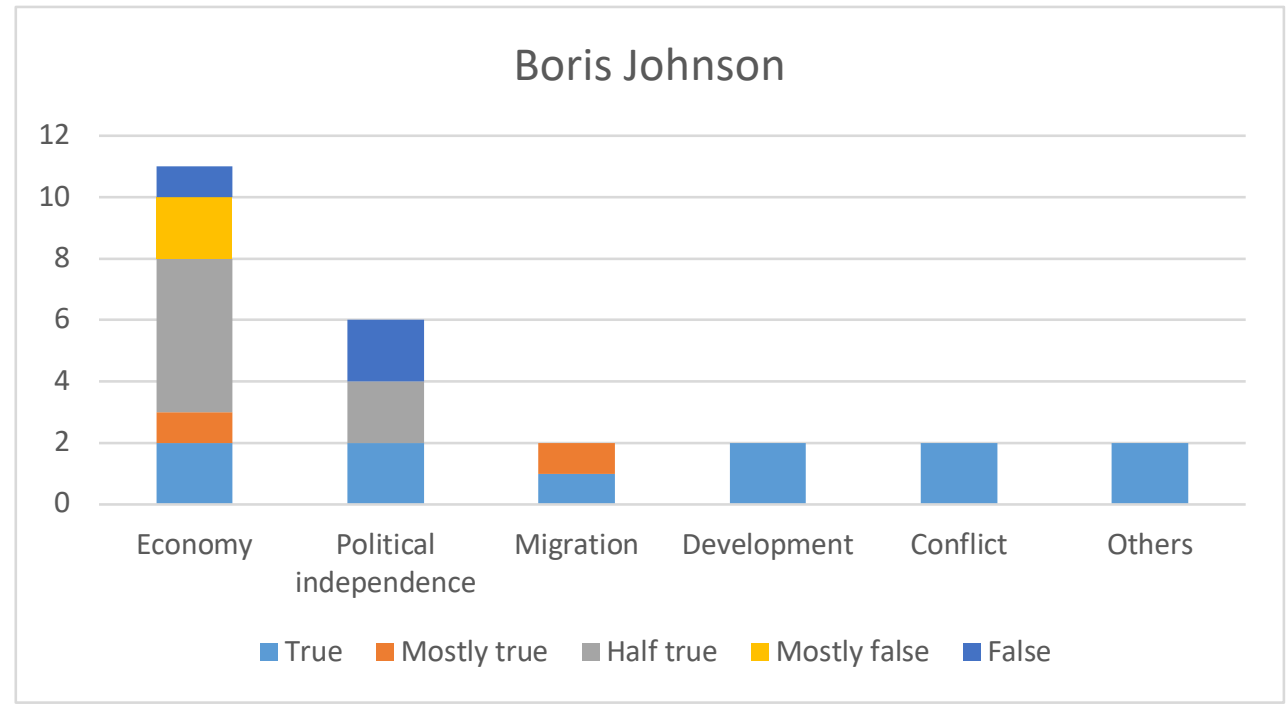

Boris Johnson, in his opening speech, states:

People are surprised and alarmed to discover that our gross contributions to the EU budget are now running at about $£ 20$ bn a year, and that the net contribution is $£ 10 \mathrm{bn}$; and it is not just that we have no control over how that money is spent.

The reality is that in 2014 , the gross contribution was of $£ 18777 \mathrm{~m}$, which can be stated as "true" when Johnson says is about £20bn. However, this statement is omitting to subtract the rebate (leaving $£ 14361 \mathrm{~m}$ ) and the public (leaving $£ 9785 \mathrm{~m}$ ) and private sector receipts (leaving $£ 8385 \mathrm{~m})(B B C, 2016)$.

In fact, the previous words represent how disinformation works in a post-truth environment: The politician not only is misrepresenting the contributions that UK gives to EU by omitting information, but he is also conferring a sentiment/reaction to it ("people are surprised and alarmed").

Dominic Cummings, Vote Leave Director, explained his selection of the fact: "we send the EU 350 million [each week]" to provoke people into argument. This selection is because first, there is not a single (definitive) set of figures of the contribution that UK gives to EU. And second, because with his huge claim, when people tried to tackle the details, they were forced to repeat the campaign's talking point. Then, this fact is provocative and a persistent tactic throughout the campaign" (in Ball, 2017: 51).

A survey conducted by ICM Unlimited, showed that of those who had heard this claim, half had heard or read materials to suggest it was false. But, despite hearing that the affirmation was false there was resistance to processing the claim as factually incorrect.

In fact, and as it was explained above, information is different from facts. One property of information is that it passes through many hands (post-truth seeks for repetition); in this process, disinformation can be catalogued as disinformation as it just if the original source does not believe the information is misleading. Any of these 
politicians will agree in that the selection of the facts is biased, but they are aware that they use not definitive figures to stretch the facts and slogans.

The posture of David Cameron is different. Most of the statements that he used are related to economy but in terms of predictions. The latter makes it harder to determine their accuracy. However, in general terms, for Remain, departure would provoke a veritable economic Apocalypse:

The European Union and Britain together is a market of 500 million people. It's the biggest single market anywhere on our planet. And we are in it. We have a say over it. And we can trade freely into it (...) Three million jobs in our country depend on trade with the European Union.

These kind of arguments are not useful to support a posture because there are assumptions that are not detailed. For instance, when talking about a market of 500 million people, it is hard to understand all the economic implications that Cameron tries to highlight. Due to this complexity, the claims are dismissed.

\section{Graph 2: "Use of facts" by David Cameron}

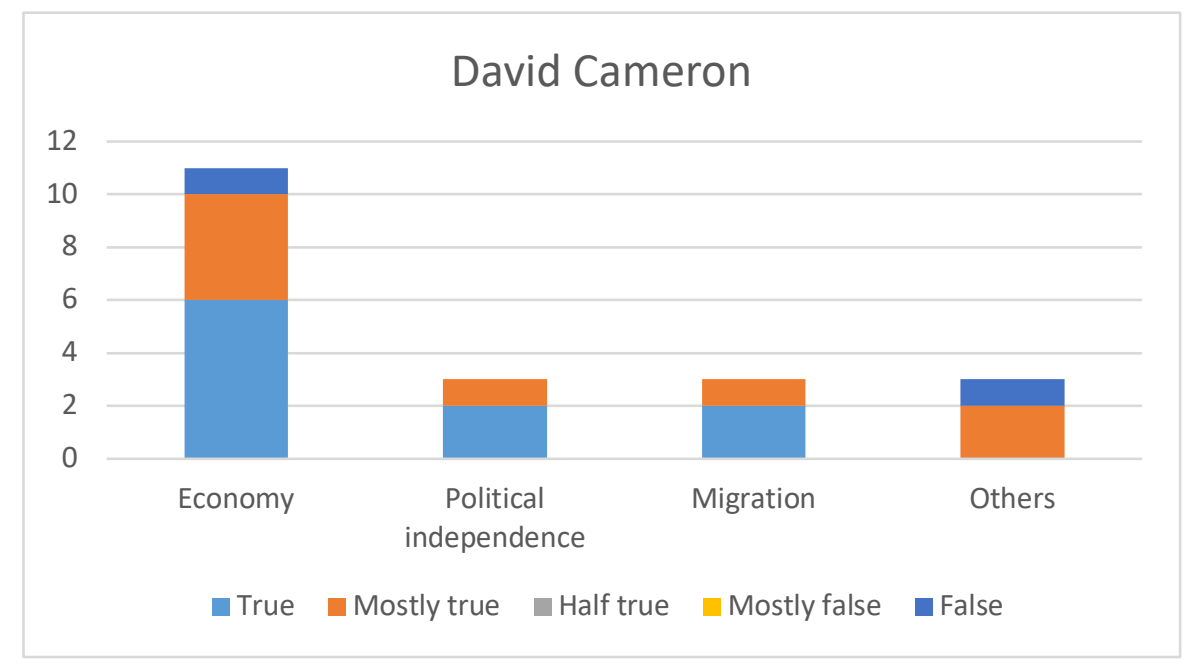

The use of facts are closely related to the fourth and fifth level of disinformation; however, in the process of circulation of the information, the way some information that is relevant is ignored or avoided has to be with the feelings/sentiments that people has already developed towards the candidates and the policies (second level of disinformation). These two codes overlap because the ultimate goal of politicians is to awake passions and they achieve this by mixing facts and expectations.

\section{Transparency}

Post-truth is also seen as a battle for attention. In fact, distraction can be the enemy of truth. In this research, transparency has been understood as the lack or absence of arguments by the use of intertextuality, assertion and assumption. The difference between transparency and misrepresentation of facts is provocativeness. Politicians prefer to deploy facts when the argument can be easily reproduced and "understood" by average 
citizens. Thus, some arguments rely on the fact that some messages instantaneously unveil the relationship between its cause and its represented effect.

For instance, Boris Johnson uses generalizations to make forced comparisons that can be very helpful when reaching the public, but that in the background do not have any real relationship:

Brussels now has exclusive or explicit competence for trade, customs, competition, agriculture, fisheries, environment, consumer protection, transport, trans-

European networks, energy, the areas of freedom, security and justice, and new powers over culture, tourism, education and youth.

Transparency is also the most used tool by David Cameron. In the opening and closing speech he decided to underline that the referendum was a "choice for a lifetime". To do so, Cameron related unclearly the referendum with power and patriotism: "So I believe the bigger Britain choice, the patriotic choice, the way to get things done in the world choice to enhance the power of this great country will be stronger inside the European Union".

The clue difference between the use of facts and the use of intertextuality, assertion and assumption (transparency) is that when politicians find that their argument is too complicated to explain, they prefer to go for transparency; they rely on people making their own associations among statements. In other words, the difference between going for the fifth or the fourth level of disinformation is the impact and the consumption of the facts.

According to Sober (1994) and his game theoretic model of deceptive lying in (disinforming is very close to deceptive lying), whether a person disinform depends on the expected costs and benefits. In particular, it depends on the costs of not being believed versus the probability of being believed. Then, transparency is a mechanism to avoid the probabilities of not being believed as it represents the simply lack of arguments. That is why it is related to the fourth level of disinformation.

\section{Interpretation and Situational Context}

It is important to remark that when reducing complex issues into a simplistic choice ("yes" or "no"), voters will not choose the type of compromise solution that elected representatives often seek.

At the start of 2016, Remain had a comfortable polling lead of eight to ten points over Leave, but the UK public did not cared about the EU. Less than one in ten UK voters listed the EU among the top three issues facing the country in the run-up of the 2015 election. In the top of the list of most important issues were immigration, the condition of the NHS and the health of the economy.

As it was mentioned before, the Remain campaign profited from the economic argument, while the Leave related the referendum to immigration. The issue voting was "tied". Then, the Leave main attack line appeared painted onto the side of a bus: "We 
send the EU $£ 350$ million a week - let's fund our NHS instead”. With this message, the Leave attached the referendum with the third remaining "top three" issue and one of the country's most beloved institutions. However, after the Leave won, "virtually no one at the core of the Vote Leave campaign believed in the literal truth of the campaign's central slogan" (Ball, 2017: 49).

Remain campaign in the figure of Cameron was characterized for being cautious. However, since post-truth is associated with impact, the Leave campaign had an important advantage. In fact, as the name "Brexit" won over "Bremain" and the referendum was globally named with the first option. This also shapes people's view of the process (Gómez García, 2016: 306).

At the end, according to Hobolt (2016), the divide between winners and losers of globalization was a key driver of the vote; preferring to "leave" was particularly common among less-educated, poorer and older voters, and those who expressed concerns about immigration and multi-culturalism.

\section{Matrix of Relations}

Keyes (2004: 151) sketches that post-truth is heavily related to narratives and the way the stories are constructed. The author states that "larger truths and narrative drive can best be achieved by relinquishing an outdated obsession with accuracy". In this line, disinformation is closely related to information literacy.

From the analysis above, there are some deductions that can be represented in the next matrix:

\section{Graph 3: Matrix of relations}

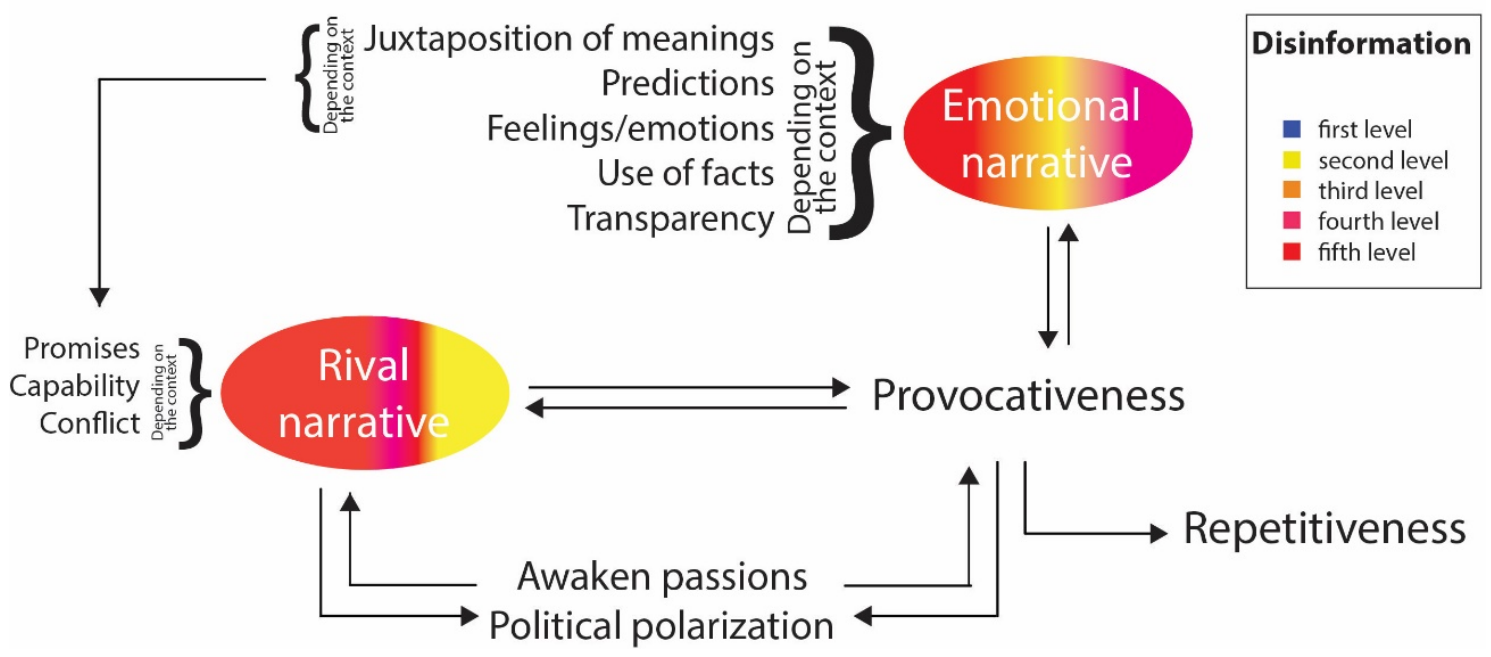

Speeches in a post-truth environment create an emotional and a rival narrative. The emotional narrative can be understood as the combination of emotional and rational 
imperatives. It is fed by the second, fourth and fifth levels of disinformation. This means that "biased" information and the omission of relevant information is important when appealing for rational arguments; however, feelings/emotions play also a key role because the public decides what they dismiss as they are also predisposed to believe.

However, the selection of the emotional narrative that the politicians will implement depends on two factors: The context and the provocativeness. The first one is related to the way the election will be address. The second one is more about the new environment that politicians want to create. Provocativeness is important because the correct set of arguments or omissions lead to the set of repetitiveness (among media and politicians). By this way, an idea is inserted among the voters. Consequently, the rule of a "lie repeated a thousand times does become the truth" can explain how important it is to provoke. Once again, disinformation is purposeful.

As a further matter, post-truth speeches are also concerned of elevating the capacity of the candidate rather than his honesty. That is why politicians ask to be taken seriously but not literally. Then, they create a rival narrative. To do so, they tend to create promises and to sow doubt about the other candidate; they create a probable reality by contrast; however, this reality is not grounded in real data.

The most important difference between rival and emotional narratives is that the first one profits from the third level of disinformation. Rival narratives do not address the policy but the person who is presenting it.

The addition of the emotional narrative and the sow of doubt (rival narrative) awakes passions among citizens. The aforementioned creates a temporary political polarization.

\section{Further Considerations}

This research aimed to link the characteristics of post-truth with the different levels of disinformation to analyze the different mechanisms that politicians can use in speeches to profit from the environment and to manipulate the public.

Firstly, by literature review and a confrontation of the possible conceptualizations of post-truth, seven characteristics for it were determined: use of facts, use of assumptions, assertion and intertextuality (transparency), legitimize the speaker's position and delegitimize the others, appeal for an emotional reaction on public, juxtaposition of meanings, make promises and predictions, creation of conflict. Then, these characteristics were linked to different levels of disinformation according to their conceptualization. These seven characteristics were found in Brexit in both sides of the campaign.

The first question $(R Q 1)$ can be answered by the understanding of the creation of narratives (emotional and rival). This can be related to the everyday-more-popular resource that is the story-telling. Narratives, just like stories, create their own bonds, "represent cohesion, shared understandings, and meanings" (Delgado, 1989). 
The use of the context to create emotional and rival narratives can be very powerful when trying to provoke citizens and when deciding which information is more useful for them to circulate.

On one hand, the mechanisms to create emotional narratives are selected in order to awake feelings and passions among the electorate. That is why politicians use emotional imperatives. Depending on what politicians expect from voters, they can seek for anger, fear or enthusiasm. This characteristic is also related to populism.

Emotional narratives are aimed to wrap facts in stories that speak to ordinary human concerns and to assign an emotion to that fact. Then, even if the facts that were used were misleading, the story fulfilled its mission as it guided people on what they should be thinking and it made them repeat the information that the politicians were willing to transmit. Then, even if the message is proven to be untrue, studies show that the brain negotiates conflicts between data and desire.

In post-truth and disinformation, the final aim of all the statements that they use is provocativeness; the more provocative an argument is, the most probable that people will repeat it. Again, repetition makes things look more plausible so politicians do not need to worry about grounding their proposals.

On the other hand, when it comes to rival narratives, politicians tend to look for conflict as a distraction from the issue that is voted as itself. That is why they tend to select statements that underline personally the differences between the other's proposals. This has also a relationship with the creation of an anti-establishment message.

In regard to the second and third research questions ( $R Q 2, R Q 3)$, the use and the abuse of all these narratives will depend of provocativeness as a clue to generate repetitiveness and, in a broader sense, distraction among the public. Then, it is easier to insert misleading, provocative statements that will be constantly repeated. The effect works because when people attempt to assess truth, they rely on two things: whether the information is understandable, and whether it feels familiar (this under the premise that the more repeated, the more familiar). Besides, disinformation is closely linked to information literacy: on how people use both cues to credibility and cues to deception will depend their judgements.

In the case of Brexit, emotional and rival narratives were constructed among the whole campaign. However, the components of each narrative varied according to provocativeness and repetitiveness. For instance, that explains how Leave and Remain campaign select their issue-framing and the juxtaposition of meanings.

All these characteristics of post-truth and their combination of different levels of disinformation are closely related to political polarization. By this time, political polarization is a reality that appears in short periods of time (i.e. Brexit referendum); the shortness is a crucial factor to intensify distractions and provocations and to awake 
feelings. Besides, it is easy to create narratives that are expected to be repeated just for a short period of time.

Post-truth has a potential causal relationship with political conflict and social volatility. However, as it has been remarked during the whole study, to understand posttruth, it is imperative to examine the context. In this case, Brexit has been analyzed from the side of the politicians, however media and citizens should also be considered to fully understand the dynamics of post-truth.

Furthermore, this study and its design has some limitations. First, as the concept of post-truth is still under construction, the results brought through the exploration of Brexit are not generalizable. However, the generalization has never been the aim of this research. Second, the CDA allows creating rich interpretations, but these interpretations are susceptible to subjectivity. Then, to strengthen validity and reliability, the with-in case evidence has been selected according to theoretical justifications; besides, the use of the software Atlas.ti contributes to decrease subjectivity. But, the units of analysis can also be examined according to the validity claims (Montgomery, 2017: 15).

In sum, post-truth and how it is related to disinformation is a relatively new phenomenon in the world of politics; thus, from the side of the academy, further research is required. This study had a deep look into politicians' speeches because they are a tangible expression of the phenomenon, but there are a lot of social and political implications underlying them. It is imperative to enhance our understanding of why and how all these conditions interact.

\section{References}

Ball, James. Post-truth: How bullshit conquered the world. Biteback Publishing: London.

BBC (2016). "Reality Check: Your questions on cost of EU membership". In https://www.bbc.com/news/uk-politics-eu-referendum-36470341

Brader T., Valentino N., and Suhay E. (2008). "What triggers public opposition to immigration? Anxiety, group cues, and immigration threat". American Journal of Political Science, 52(4): 959-978.

Carver CS and Harmon-Jones E. (2009). "Anger is an approach-related affect: evidence and implications". Psychological bulletin, 135(2): 183-204.

Clarke, Harold, Matthew Goodwin and Paul Whiteley (2017). "Why Britain Voted for Brexit: An Individual-Level Analysis of the 2016 Referendum Vote". Parliamentary Affairs. N. ${ }^{\circ} 70: 439-464$.

Colvile (2016). "12 people who brought about Brexit". In https://www.politico.eu/article/12-people-who-brought-about-brexit-leaveremain-referendum-campaign-euroskeptics-tension/ 
D'Ancona, Matthew (2017). Post-truth: The New War on Truth and How to Fight Back. Ebury Press: London.

Delgado, Richard (1989). "Storytelling for Oppositionists and Others: A Plea for Narrative”. Michigan Law Review, Vol. 87, No. 8: 2411-2441.

Ditto, Peter and David F. Lopez (1992). "Motivated Skepticism: Use of Differential Decision Criteria for Preferred and Nonpreferred Conclusions". Journal of Personality and Social Psychology, Vol. 63, No. 4: 568-584.

Drake, Matt (2017). "EU 'spreading Soviet-style propaganda and disinformation' to undermine $\quad$ UK $\quad$ Brexit $\quad$ support" https://www.express.co.uk/news/politics/866601/eu-brexit-european-union-jeanclaude-juncker-commission-john-redwood-theresa-may

Druckman JN and McDermott, R. (2008). "Emotion and the framing of risky choice". Political Behavior, 30(3): 297-321.

Fairclough, Norman (2003). Analyzing Discourse. Textual analysis for social research. Routledge: London and New York.

Fairclough, N. (2001). Language and power (Language in social life series). Harlow: Pearson.

Fetzer, James (2004). "Disinformation: The Use of False Information". Minds and Machines 14: 231-240.

Fuller, Steve (2016). "Embrace the Inner Fox: Post-Truth as the STS Symmetry Principle Universalized". In https://social-epistemology.com/2016/12/25/embrace-theinner-fox-post-truth-as-the-sts-symmetry-principle-universalized-stevefuller/\#comments

Golitsyn, Anatoliy (2016). New Lies for Old: The Communist Strategy of Deception and Disinformation. CreateSpace Independent Publishing Platform.

Gómez García, Ignacio (2016). "The Brexit and Trump cases from engineering in social Communication”. Razón y palabra, Vol. 21, No. 96: 295-319.

Higgins, Kathlenn (2016). "Post-truth: a guide for the perplexed". Nature, Vol. 540: 9.

Hobolt, Sara (2016). "The Brexit vote: a divided nation, a divided continent". In Journal of European Public Policy, Volume 23, Issue 9.

Hoes, Emma (2017). “About Post-factualism, Populism and Bullshit: Using discourse analysis to identify post-factualism in populist and non-populist speech during the 2008 and 2016 US Presidential Elections". Master Thesis presented with a view to obtaining the degree of Master in Political Science, Universitat Autònoma de Barcelona. 
Jasanoff, Sheila (2004). States of Knowledge: The Co-Production of Science and Social Order. London: Routledge Taylor and Francis Group.

Kawulich, Barbara (2005). "Participant Observation as a Data Collection Method". Volume 6, No. 2.

Keyes, Ralph (2004). The Post-Truth Era: Dishonesty and Deception in Contemporary Life. St. Martin's Press. Kindle Edition.

Lynch, Michael (2017). “STS, symmetry and post-truth”. Social Studies of Science, Vol. 47(4): 593-599.

Mason, Jennifer (2002). Qualitative Researching. Sage Publications: London.

Masters, Jonathan (2018). "Russia, Trump, and the 2016 U.S. Election". In https://www.cfr.org/backgrounder/russia-trump-and-2016-us-election

Montgomery, Martin (2017). "Post-truth politics?". Journal of Language and Politics, 16 (4): 619-639.

National Endowment for Democracy (2017). "Issue brief: distinguishing disinformation from propaganda, misinformation, and "fake news". In https://www.ned.org/issue-brief-distinguishing-disinformation-frompropaganda-misinformation-and-fake-news/

Newman, Eryn J. Maryanne Garry, Daniel M. Bernstein, Justin Kantner and D. Stephen Lindsay (2012). "Nonprobative photographs (or words) inflate truthiness". Psychonomic Bulletin \& Review, Vol. 19, Issue 5: 969-974.

Oxford Dictionaries (2018). "Post-truth". In https://en.oxforddictionaries.com/definition/post-truth

Polifact (2018). "The Principles of the Truth-O-Meter: PolitiFact's methodology for independent fact-checking". In http:/www.politifact.com/truth-ometer/article/2018/feb/12/principles-truth-o-meter-politifacts-methodology-i/

Roberts, David (2010). “Post-truth politics”. In https://grist.org/article/2010-03-30-posttruth-politics/

Rose, Jonathan (2016). "Brexit, Trump, and Post-Truth Politics”. Public Integrity, 19:6, $555-558$.

Schattschneider, E. (1960). "The semisovereign people". In http://wikisum.com/w/Schattschneider:_The_semisovereign_people

Shipman, Tim (2016). All out war: The full story of Brexit. William Collins: Kindle version. 
Sober, E. (1994). "The primacy of truth-telling and the evolution of lying". In From a biological point of view, Cambridge, Cambridge: 71-92.

Sprandel, Marcia Anita (n/d). "Resenha Poovey, Mary. 1998. A History of the Modern Fact: Problems of Knowledge in the Sciences of Wealth and Society". In http://www.scielo.br/pdf/mana/v9n1/a14v09n1.pdf

The Economist (2016). "Art of the lie". In https://www.economist.com/news/leaders/21706525-politicians-have-alwayslied-does-it-matter-if-they-leave-truth-behind-entirely-art

Van Dijk, T. (2005). "Ideología y análisis del discurso". Utopía y praxis latinoamericana, 10(29). In http://www.produccioncientificaluz.org/index. php/utopia/article/viewFile/2703/2703

Varguillas, Carmen (2006). "El uso de Atla.ti y la creatividad del investigador en el análisis cualitativo de contenido Upel”. Revista de Educación Laurus, N. ${ }^{\circ} 12$.

Vasilopoulou, Sofia and Markus Wagner (2017). "Fear, anger and enthusiasm about the European Union: Effects of emotional reactions on public preferences towards European integration". European Union Politics, 18(3), March.

Vegetti, Federico (2014). "From political conflict to partisan evaluations: How citizens assess party ideology and competence in polarized elections". Electoral Studies 35: $230-241$.

Weedon, Jen, William Nuland and Alex Stamos (2017). Information Operations and Facebook. In https://fbnewsroomus.files.wordpress.com/2017/04/facebook-andinformation-operations-v1.pdf

Westen, Drew (2007). The political brain. The role of emotion in deciding fate of the nation. Public Affairs: New York. Kindle edition. 